\title{
Перспективы культивирования партенокарпической яблони
}

Терлеикий В.K. ${ }^{1 *}$ к.б.н., доцент; Решетюк О.В. ${ }^{2}$ к.б.н., доцент.

${ }^{1}$ Луцкий институт развития человека Университета «Украина», Луик, Украина;

${ }^{2}$ Черновицкий начиональный университет им. Ю. Федьковича, Черновиы, Украина.

*e-mail:filipter@rambler.ru

Описаны результаты культивирования партенокарпической яблони «Буковинка» на Украинском Полесье (Волынская область). Рекомендованы способы размножения этой яблони прививками и окулировками. Обоснованы перспективы распространения «Буковинки» в северных широтах, где существуют трудности опыления плодовых.

Ключевые слова: партенокарпия, плодоводство, прищепа, подщепа.

\section{The prospects of parthenocarpal apple-tree's cultivation}

Terletsky $V$. candidate of biological science, docent of Lutsk man development institute at University "Ukraine" (Lutsk, Ukraine)

Reshetjuk O. candidate of biological science, docent of Cherniwetsky National University (Cherniwtsy, Ukraine).

There are results of parthenocarpal apple-tree's cultivation at Ukrainian Polissya described (Vohlyn region). The authors have recommended the methods of this apple-tree reproduction by grafting and spotting. The prospects of parthenocarpal apple-tree spreading in north latitudes havebeen motivated, where are existing difficulties with fruits pollination.

Key words: parthenocarption, fruit-growing, slip-engraft, bud-engraft.

Партенокарпические формы встречаются как естественные мутации у плодовых, когда плоды образуются не в результате оплодотворения, а саморазвитием цветоложа. В частности, у Malus domestica Borkh. они известны как сорты «Чудачка» и «Матрешка», в Белорусии - «Дарунак» (вегетативная партенокарпия) [3]. Есть партенокарпические яблони и в Украине, хотя они мало изучены и редко культивируются в практике садоводства. Вместе с тем использование партенокарпических форм в селекции является чрезвычайно перспективным направлением садоводства, учитывая не только биологическую уникальность партенокарпии, а и ее высокие потенциальные возможности, в первую очередь, их стойкость против вредителей и болезней, а также полную независимость от насекомых опылителей [1-3]. Последнее крайне важно для северных регионов, где климатические условия создают 
для садоводства дополнительные сложности (отсутствие опылителей, неблагоприятные погодные условия в период цветения плодовых и т.д).

Изучали на протяжении 2001-2019 гг. партенокарпическую яблоню M. domestica буковинского происхождения (Черновицкая область), которую культивировали в условиях Полесья (Волынская область). Материнское дерево произрастало на частном садовом участке (г. Сторожинец Черновицкой области) еще в начале прошлого века, а позднее (в 90-х годах) оно погибло. Размножали партенокарпическую яблоню, названную нами «Буковинка», прививками в 2 срока: весенними черенками в апреле и летними почками в августе (окулировкой). Для подщеп использовали дички M. domestica. В обоих случаях процент приживания прищеп оказался достаточно высоким и составил соответственно 90 и 86 \%. Таким образом, размножение партенокарпической яблони «Буковинки» обычными для садоводства методами не составляет особенных трудностей для распространения этого перспективного сорта в культуре.

Анализ хода роста «Буковинки» показал достаточно стабильные показатели годичных приростов, на которых мало сказывались местные экстремальные зимние температуры, которые в отдельные годы понижались до -25-30 ${ }^{\circ} \mathrm{C}$. Сорт «Буковинка» не страдает от изменчивости погодных условий (суровые зимы, ранневесенние заморозки, засуха и т.д.) и, что особенно важно, от отсутствия насекомых-опылителей. По показателям приростов экспериментальные экземпляры «Буковинки» существенно превышают большинство местных сортов $M$. domestica, которые произрастают рядом (в среднем, на 8-16 \%). Кроме того, в сравнении с ними «Буковинка» совсем или почти совсем не поражается вредителями и болезнями, в частности тлей, долгоносиками, плодожорками, мучнистыми грибами, паршой, раком. Эти особенности партенокарпической яблони особенно ценны для практического садоводства в условиях Полесья.

Первое цветение прищеп наблюдается на второй год после прививки (в отдельных случаях единичное распускание цветков - 1-3 шт./пог. м побега - можно получить уже в первое лето). Эти цветки имеют своеобразную для партенокарпических видов M. domestica, структуру. Они полностью лишены лепестков и пестиков. Цветок окружен только чашелистиками, которые образуют своеобразную форму «чашечки». Такая структура цветка послужила причиной народного названия «Буковинки»: «Яблоня, которая не цветет, а плодоносит».

Цветки «Буковинки» появляются в пазушных соцветиях по 1-3 шт., но на протяжении первых 3-4 лет после прививки плодов они не образуют и осыпаются. Эта особенность характерна прищепам, кроме которых на подщепах сохраняются побеги материнского сорта или другие генерирующие прищепы. Мы это явление считаем биологическим «тяготением» подщепы к 
более прогрессивному плодоношению путем опыления и полового оплодотворения цветков на побегах, которые сохранили эту способность типичных цветковых растений. Если подобных побегов на подщепе нет, плодоношение «Буковинки» наступает раньше.

«Буковинке» также не присуща способность повторного цветения в августе-сентябре, которое в отдельные благоприятные годы можно наблюдать у яблонь местных сортов. Следует отметить, что повторное цветение у местных сортов $M$. domestica Волынской области не заканчивается плодоношением, в отличие от такого же явления у Rubus idaeus L. и других представителей семейства Rosaceae, а потому оно не имеет существенного значения для плодоводства.

Первые плоды на ветках «Буковинки» образуются на 5-6 год после прививки. Сначала они единичные, размером не более 7-8 см в диаметре. Плоды созревают в конце июля - в начале августа. Они имеют характерную пестро-розовую окраску поверхности, сладкие на вкус и ароматные. Следует отметить, что на срезе плода проявляются типичные признаки партенокарпии: полное отсутствие семян и окруженных пленками семенных камер. Плоды «Буковинки» хорошо сохраняются на протяжении осени и не теряют при этом высоких вкусовых качеств.

В последующие годы интенсивность плодоношения «Буковинки» резко возрастает и в возрасте 15-20 лет достигает 6-8 пл./пог.м (110 140 кг/дерево). Плодоношение этого сорта достаточно стабильно и не уменьшается больше чем на $10-15 \%$ в экстремальные по погодным условиям годы. Одновременно увеличиваются размеры плодов до 10-12 см в диаметре и улучшаются их качественные характеристики.

Выводы. Партенокарпическая яблоня Malus domestica сорта «Буковинка» целиком перспективна для широкого внедрения ее в культуру плодоводства не только в условиях Прикарпатья (Буковины), а и в более северных широтах Полесья Украины. Ее положительные особенности (стойкость при значительных перепадах температур и экстремальных изменениях погоды, стойкость против вредителей и болезней, высокое качество плодов и независимость плодоношения от наличия насекомых-опылителей) свидетельствуют о перспективности распространения сорта «Буковинки» в культуре садоводства, что крайне важно для более северных широт, где активность насекомыхопылителей существенно ограничена.

\section{Список литературы}

1. Гюльмагометова Ш.А. Использование медоносных пчел для формирования урожая яблони в адаптивно-ландшафтной технологии плодоводства Республики Дагестан. Автореф. диссерт. канд.сельхоз.наук. / Ш.А. Гюльмагомедова. - Ставрополь: 2004. $-20 \mathrm{c}$.

2. Козлов Н.Е. оценка перспективности плодовых сортов яблони по содержанию флавоноидов в генеративной сфере цветков. Автореф. дисссерт. канд.сельхоз.наук. / 
Н.Е. Козлов. - Мичуринск: 2012. - 23 с.

3. Седов Е.Н. Программы, методы, приемы селекции яблони, их развитие и совершенствование. / Е.Н. Седов. // Вавиловский журнал генетики и селекции. - Т.17, №3, 2013. - C.487-498.

DOI 10.18699/GPB2020-113

\section{Исследование мутагенного эффекта фосфемида на генотипах яч- меня по полевой всхожести семян и разнообразию мутаций}

Тетянников Н.В. ${ }^{l}$, к.с.-х.н., н.с.; Боме H.A. ${ }^{2}$, д.с.-х.н., профессор; Вайсфельд Л.И. ${ }^{3}$, главный спещиалист.

${ }^{I}$ ФГБНУ «Всероссийский селекиионно-технологический институт садоводства и питомниководства», Москва, Россия, tetyannikovnv@уа.ru;

${ }^{2}$ ФГАОУ ВО «Тюменский государственный университет», Тюмень, Россия, bomena@mail.ru;

${ }^{3}$ Институт биохимической физики им. Н.М. Эмануэля Российской Академии наук, Москва, Россия, liv11@yandex.ru.

В статье показана возможность использования химического мутагена фосфемида для расширения генотипического разнообразия ячменя. Определена реакиия изучаемых образиов на обработку мутагеном по полевой всхожести семян. Получены мутантные популяции, различающиеся по частоте и спектру мутаций. Выделены перспективные формы ячменя, которые могут быть использованы в качестве исходного материала в селекиионных программах.

Ключевые слова: ячмень, индуцированные мутации, мутационная селекиия, ценный признак, химический мутаген.

\section{Research of the mutagenic effect of phosphemide of barley genotypes on field germination of seeds and the variation of mutations}

Tetyannikov N.V.' ${ }^{1}$, Bome N. A. ${ }^{2}$, Weisfeld L.I. ${ }^{3}$.

${ }^{1}$ All-Russian Horticultural Institute for Breeding, Agrotechnology and Nursery, Moscow, Russia.

${ }^{2}$ University of Tyumen, Tyumen, Russia.

${ }^{3}$ Emanuel Institute of Biochemical Physics of Russian Academy of Sciences, Moscow, Russia.

In article was presented the possibility of using of the chemical mutagen phosphemide for expansion of the genotypic diversity of barley. The reaction of the studied samples to treatment with a mutagen on the field germination of seeds was determined. Mutant populations differing in the frequency and spectrum of mutations were obtained. Promising forms of barley that can be used as starting material in breeding programs were highlighted. 